\title{
Ecoutopia from Fiction to Fact: An Interview with Heather Alberro
}

\author{
Heather Alberro (Corresponding author) \\ Nottingham Trent University, United Kingdom \\ Email: alberro90@gmail.com \\ ORCID: https://orcid.org/0000-0003-1031-5746
}

Received: $17 / 05 / 2020$

Accepted: 19/06/2020

Published: 01/07/2020

Volume: 1 Issue: 2

How to cite this paper: Alberro, H. (2020). Ecoutopia from Fiction to Fact. Journal of Critical Studies in Language and Literature, 1(2), 44-47

DOI: https://doi.org/10.46809/jcsll.v1i2.10

Copyright (C) 2020 by author(s) and Global Talent Academy Ltd. This work is licensed under the Creative Commons Attribution International License (CC BY 4.0).

http://creativecommons.org/licenses/by/4.0/

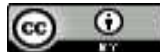

\begin{abstract}
Human is at the heart of the story of climate change in the Anthropocene where, according to Dipesh Chakrabarty (2012), human behaviors have influenced the environment and created a distinct geological epoch. Current climate change issues are largely human induced. This implies that the human species is now part of the natural history of the planet. In November 2016, Stephen Hawking warned that humanity has 1000 years to leave the earth due to climate change, but in his most recent BBC documentary aired on June 15, 2017 called Expedition New Earth, he suggested humans have just 100 years left before doomsday. In spite of such warnings and writings, Donald Trump withdrew America from the Paris Climate Agreement on June 2017, on the same day, satellite images showed that a huge mass of ice in an area of five thousand square kilometres was breaking away from the Antarctic continent under the impact of rising temperature. It seems that Trump's act is beyond ecological consideration as he believes the agreement could "cost America as much as 2.7 million lost jobs by 2025". Projections of climate change, however, have shown horrible scenarios involving a central economic metropolis such as New York losing much of its lands because of rising sea levels. The inhabitants of such areas will have to uproot their communities and cultures to move to less vulnerable lands. Thus, it is important to examine how ecoutopian literature is responding to the conditions of the human being in this epoch. In the following interview, Heather Alberro has answered to some questions on climate change, the conditions of human being in the Anthropocene, and the role of literature and culture in relation to environmental issues.
\end{abstract}

Keywords: Ecoutopian Fiction, Anthropocene, Climate Change, Ecocriticism

\section{Biographical Note}

Heather Alberro recently completed her $\mathrm{PhD}$ at Nottingham Trent University's Department of Politics and International Relations, as part of the 'Ethics, Ecology, \& Identity' research group. Her background and interests span a range of disciplines including green utopianism, critical posthuman theory, environmental sociology, environmental ethics, ecocriticism, and political ecology. Her publications include an article entitled 'Valuing Life Itself': On Radical Environmental Activists' Post-Anthropocentric Worldviews' published in 2020 in the Journal of Environmental Values, and 'Interspecies' in the upcoming The Cambridge Companion to Literature and the Anthropocene. Heather also serves as coconvenor for the Political Studies Association's (PSA) environmental politics specialist group, as Chair of the PSA's Early Career Network (ECN), and writes frequently for The Conversation UK. 


\section{Interview}

Heather Alberro is a lecturer at Department of Politics and International Relations, Nottingham Trent University. Her research centres on an ecocritical examination of radical environmental activists (REA's) as contemporary ecoutopian manifestations amid the socio-ecological perturbations of the Anthropocene.

JCSLL ${ }^{1}$ : We might start by asking you about the idea of 'harmony' between human and nature. The ecological critics and thinkers sometimes observe nature as the jungle that is being destroyed by humans. In this regard, Timothy Morton (2007) argues that such existing dualism between the human being and nature is the main philosophical reason for humans' destruction of the environment. He then suggests that "if we experience the fact that we are embedded in our world, then we would be less likely to destroy it". Likewise, Ashton Nichols (2011) stresses that we are part of nature. Moreover, he depicts

an environmental criticism grounded in "urbanature" in which distinction between human and environment is blurred, and suggests that all humans and nonhumans are "in a complex web of interdependent interrelatedness". Do you think that the modern ecological consciousness is seeking the 'harmony' between human and the natural world, and a utopian ecology is one in which humans, plants, animals live in such harmony that none destroys or dominates the other?

$\mathbf{H A}^{2}$ : From recent social movements like Extinction Rebellion to more radical green groups such as Earth First!, and increasingly amidst mainstream discourses, we are seeing a growing chorus of voices calling for a radically new relationship between humans and the non-human world. This is, after all, the core of green utopianism- a striving for structural and qualitative transformations between social and ecological systems, towards modes of relationality that are more ethical and resilient, less hierarchical and more egalitarian. Green utopian experiments in the form of intentional communities, social movements and in literary form have explored and attempted to realise these visions for hundreds of years, and there has been a new upsurge since the 1970's in response to mounting climate and ecological crises, However, as you point out, there is a danger lurking in certain discourses and narratives that frame humans as inherently destructive and, in calling for things like mass 'Nature' preserves utterly devoid of human presence and/or interference, unwittingly reproduce long-standing human-nature dualisms. Philosophers and theorists such as Val Plumwood, Timothy Morton (as you note) and Bruno Latour have long pointed to the problematic nature- from an ethical and political perspective- of these discourses. Firstly, these perspectives are ontologically false- as there is no such thing as a neat separation between 'humans' or human settlements and 'nature' or other organisms. Secondly, these approaches are predicated- and reproduce- longstanding Western hierarchical and dualistic constructs of the human-animal-nature relationship, which have traditionally framed humans as separate from and superior to the nonhuman world. Humans have long been framed as what Plumwood refers to as a 'Master identity', portrayed as categorically distinct from nonhumans, while the latter have in turn been labelled as inferior in relation to the former- by lacking 'souls', rationality or language, for instance. The structure of antagonistic dualisms that underpin Western thought elevate the 'Master identity'- traditionally not only humans but also the white, Christian, European maleand reduce all 'others' to an inferior status. This mode of thought is still deeply entrenched in how we (largely in the West) perceive and relate to the nonhuman world.

So, crucially, we need a paradigm and value shift as much as a technical and socioeconomic one. We need to radically reconfigure our notions of the collective 'we', of who/what we value and why. The work of posthuman scholars such as Rosi Braidotti, Bruno Latour and Jane Bennett shed some light on potential pathway ahead. They call for onto-epistemological shifts in how we relate to the world, realizing that we are always enmeshed with- and composed by- multitudes of agentic 'others'. The thousands of microbes that form the human 'microbiome' constitute our skin, DNA, help us digest our food, breathe and live. Plants and other photosynthetic organisms produce the oxygen that we need to breathe. We are constituted by relations with others, to the extent that there is no such thing as an isolated 'Self'. And now in particular, amidst the boundary-defying era that is the Anthropocene, we are seeing Earth others retaliate to our transgressions. We need to learn to co-inhabit the increasingly uncertain terrain ahead with multitudes of others- human and non-human. This has to involve the careful and uncertain work of learning about who we live with and depend on in particular spatial-temporal contexts. There is no 'outside', no place where humans can retreat to exist alone and apart from 'Nature'. We will face numerous challenges as we learn to live on an increasingly inhospitable planet, but there is comfort in the thought that we don't have to do this alone. Co-constructing multispecies assemblages is the urgent task of the Anthropocene.

JCSLL: Do ecoutopian fiction help us think of alternative futures in relation to environment? Have ecoutopian visions had serious contribution in global policy discourse and considered major changes in the formation of environmental futures over the past 50 years?

HA: Ecoutopian works of fiction have certainly had a wide-reaching impact well beyond the realm of literary studies. Ernst Callenbach's Ecotopia, which lent the genre its name, has inspired bioregional and environmental movements for decades since its release in 1975. Even before the publication of Callenbach's seminal work came Aldous Huxley's Island, which is 
believed to have at least partly inspired subsequent ecoutopian literary works by Callenbach and others. These works variedly envision and explore more socio-ecologically resilient alternatives which often permeate the public imagination in complex ways. It's curious to note the proliferation of ecoutopian literary works as well as ecoutopian social movements from the 1970s and 1980s (a notable literary example is Ursula Le Guin's Always Coming Home, published in 1985), suggesting that perhaps they are responding to a general zeitgeist or widespread sensibility- that ecological crises are worsening, and that radical transformations in production, consumption, and general subsistence patterns, as well as in values and worldviews, are of the essence.

JCSLL: How do you feel about the efficiency of ecocriticism and its debates about the end of nature to the recent emergence of the idea of the Anthropocene? In addition to the jeremiad side of ecocriticism, though, the tendency to criticize our species for its destructive impacts on the planet, do you see a utopian dimension to the field, which leads scholars to identify and comment on idealistic texts that imagine how to improve our species and our civilization?

HA: Discourses around the 'end of Nature' are useful and important in my view, for some of the reasons suggested earlier. They dismantle long-standing Human/Nature binaries which suggest that there is such a thing as a human or social realm that is separable from a 'Natural' one. 'Nature' as an idyllic, harmonious state devoid of significant upheavals (until the arrival of humans') is a myth, and a highly problematic one at that. This approach continues to underpin contemporary social movement discourses and approaches to conservation (i.e. the practice of 'fortress conservation') which variedly argue that nature should be completely devoid of human presence and interference. But in the Anthropocene in particular there is no such thing as human spaces in one area and 'Nature over yonder'. We are all thoroughly and inextricably embedded in multispecies assemblages. What we need to do is radically rethink how we perceive and value nonhuman 'others', and devise ways to live well together.

Another issue is that some Anthropocene narratives which frame a homogenous 'humanity' as destructive grossly override the complexity within that category. Historically and presently there have been considerable inequalities in ecological footprints; the Global North as a whole has traditionally enriched through dispossessing and exploiting people and resources from the Global South, and even within countries, there are extreme inequalities that produce differential impacts on the natural world. The global plutocratic elite, a handful of billionaires who now own more wealth than half the world, and their profligate lifestyles exert far greater carbon and ecological footprints than most people combined. So, when discussing issues around culpability, it is important not to lose sight of these nuances.

JCSLL: How do you feel about the role of literature and culture in rising citizens' awareness about the issue of climate change? Amitav Ghosh's The Great Derangement: Climate Change and the Unthinkable examines the condition of literature and culture in the era of the Anthropocene. He argues that literature has approached climate change with silence. In addition, Fredrick Albritton Jonsson (2016) examines Amitav Ghosh's observation and argues, "How can we explain the fact that writers of fiction have overwhelmingly failed to grapple with the ongoing planetary crisis in their works?" He then continues, "For Ghosh, this silence is part of a broader pattern of indifference and misrepresentation. Contemporary arts and literature are characterized by 'modes of concealment that prevent people from recognizing the realities of their plight." My question is that how do you see the 'concealment'? And what do you think of this 'silence'?

HA: I think literary scholars and artists are beginning to respond to the sense of crisis and upheaval that is pervading popular culture and discourse. The novel sub-genre of 'climate fiction' (cli-fi) has arisen in response to the proliferation of climate and ecological crises since the 1970s/'80s. What I do perceive is a seeming paucity of green utopian or ecoutopian works, which are desperately needed amidst the increasingly dystopian conditions we find ourselves in. On the one hand, it's easy to understand why dystopian works have become so popular- from Netflix series such as The Rain and Snowpiercer to films and eco-dystopian literary works. These are a logical response to the times, which are increasingly marked by a sense of uncertainty and insecurity. We are in the midst of the planet's Sixth Mass Extinction event and a general loss of life is plaguing the globe; climatic perturbations such as sea level rise, doubts, wildfires and violent storms will displace hundreds of millions- human and nonhuman- by as early as 2050 . However, ecoutopian/green utopian works are needed more than ever in order to remind us of the infinite potentiality that continues to surround 'reality', that no matter how bleak the present conditions seem, there are always other ways to live.

JCSLL: According to Ghosh in "Where is the fiction about climate change?", "We have entered a time when the wild has become the norm". He argues that if literary works do not recognize anthropogenic climate change, they will have failed. He observes this failure as a cultural phenomenon: "their failures will have to be counted as an aspect of the broader imaginative and cultural failure that lies at the heart of the climate crisis." It is culture that, according to Ghosh, "generates desires - for vehicles and appliances, for certain kinds of gardens and dwellings - that are among the principal drivers of the carbon economy." Do you think that this failure to depict both climate and cultural crises is a silence to the exploitation of both nature and human being in the Anthropocene? 
HA: As I alluded to above, there does seem to be a failure of imagination of sorts, though perhaps more with regards to speculative works that imagine better worlds. However, cultural norms are quite significantly implicated in the Anthropogenic crises that we are seeing today. In particular, the neoliberal form of capitalism that has dominated much of the globe- not only in terms of how socioeconomic systems are structured but also our norms and values- since the 1980s. Western/neoliberal capitalism propagates greed, hyper-individualism and competitiveness as natural and socially beneficial 'norms'. It pedals endless growth, consumption and profit-maximisation, on which it is predicated, as the overarching objective of socioeconomic systems. In service of these aims, everything- even living entities- are reduced to tradable and sellable commodities to be exploited for profit maximization. This corrodes interpersonal relations, wherein people and other species are reduced to mere things with a quantifiable value rather than being seen as singular and irreplaceable kin. These aspects of our culture haven't received sufficient attention, both within literary works and in wider policy and academic discourses. It is, of course, no easy feat to address issues that are so widely and deeply embedded in so many aspects of modern life, but we must attempt to do so nevertheless.

\section{References}

Chakrabarty, D. (2012). Postcolonial Studies and the Challenge of Climate Change, New Literary History 43 (1), 1-18

Nitzke, S., \& Horn, E. (2020). Cultures of Climate. On Bodies and Atmospheres in Modern Fiction: An Introduction. Ecozon@: European Journal of Literature, Culture and Environment, 11(1), 1-8.

Ghosh A. (2016). The Great Derangement: Climate Change and the Unthinkable. The University of Chicago Press.

Ghosh A. (2016). Where is the fiction about climate change? Guardian Books Network.

Morton, T. (2007). Ecology without Nature: Rethinking Environmental Aesthetics. Cambridge: Harvard University Press.

Nichols, A. (2011). Beyond Romantic Ecocriticism: Toward Urbanatural Roosting (Nineteenth Century Major Lives and Letters). New York: Palgrave Macmillan.

Zimmerman, L. (2020). Trauma and the Discourse of Climate Change: Literature, Psychoanalysis and Denial. Routledge.

\section{Endnotes}

${ }^{1}$ Journal of Critical Studies in Language and Literature

${ }^{2}$ Heather Alberro 